\title{
Efficiency Measurement of Maintenance Costs on Customer Service Process PT Indonesia Comnets Plus West Java
}

\author{
Ika Rizky Setyaningrum \\ Bachelor of Science in Management Business Technology and Informatics \\ Telkom University \\ ikarizkys@telkomuniversity.ac.id \\ Palti Marulitua Sitorus \\ Bachelor of Science in Management Business Technology and Informatics \\ Telkom University
}

\begin{abstract}
Information technology is growing rapidly. The problems arising in the conjunction magnitude of information technology devices are how to manage, maintain, and calculate the amount of required investments. The purposes of this study are to measurepreventive and corrective cost optimization maintenance which determines the most optimal performance for alternative maintenance activity. The case studies in this research is PT Indonesia Comnets Plus (ICON +) West Java focusing on how the process of customer service telecommunication maintenance. Analysis techniques used are descriptive and optimization analysis. The level of corrective maintenance costs are known through services damage probability, average cost of service damage in the period of 2011-2014, and corrective cost analysis formula. To determine the level of preventive maintenance costs, it requires the calculation of damage probability screened estimated monthly service and then calculating the total cost of preventive maintenance. The analysis requires amount of damage and cost of protecting canceling services. The result, general implementation of maintenance services has been running well, but not optimal. Period of preventive maintenance services can be optimized with an average of 12-month treatment.
\end{abstract}

Keywords: maintenance, maintenance cost, preventive maintenance, corrective maintenance.

\section{INTRODUCTION}

Information technology is developing very rapidly. All the elements in carrying out life, organizations, companies and others cannot be separated from the role of information technology (Suroso, 2014). Implementation of information technology needs necessary care and maintenance in network and devices infrastructure. It aims to facilitate the identification and numbering of IT infrastructure, assist the development of preventive of any infrastructure plan, facilitate the monitoring of the infrastructure condition, and maintain all infrastructures including physical infrastructure so that the condition can be properly maintained (Agustin, 2012).

Competition in the telecommunications industry is increasingly stringent, so that companies operating in this industry need to have a strategy and competitive advantages to be competitive. ICON+ believes that the growth of the national telecommunications will remain high with the potential of over $10 \%$ per year, so the need for network connectivity to support mobile business data, internet and information technology services will continue to increase (Management PT. ICON+).

The results of the failure of maintenance can be damaging, causing discomfort, generate waste, and costly in terms of human or material (Heizer, 2010). Construction company is more oriented to customer satisfaction so that the basic things that must be considered by the company is ready to use machine for customer service at any time (Subakir, 2010). Through the method of optimization of maintenance, reliability and availability of assets will increase at a low cost (Kabib 2009).

To minimize disturbance, PT. ICON+ Regional West Java is applying maintenance business. However, the company certainly requires measurement of the efficiency of the maintenance costs of the company's customer service. Through the implementation of 
optimal maintenance on equipment and facilities services, the possibility of damage can be minimized or avoided altogether.

\section{METHODS}

Maintenance is a merger of any act or activity undertaken to maintain, or restore a device, machine, building on acceptable conditions (Margono, 2006). Maintenance is all activities involved in maintaining the system so that the equipment still works (Heizer, 2010). Maintenance is performed at predetermined time intervals, or to other criteria outlined, and is intended to reduce the likelihood of the other parts not meeting the acceptable conditions (Corder, 1996).

Maintenance is done to repair a section (including adjustment and repair) which has been stalled to meet an acceptable condition (Corder, 1996). Efficiency is the actual output as a percentage of the effective capacity that actually has been achieved (Heizer, 2011). Efficient is emphasizing the achievement of target and pressing the use of inputs to a minimum on the company's business processes (Kosasih, 2009).

Maintenance and Budget Relationship, the balance of the cost of maintenance repair and preventative maintenance cost are very necessary to look out for an operations manager. The operations manager should be able to take a decision, when he took the decision to make improvements, namely at the point of achieving optimal maintenance cost curve of Maarif (2013).

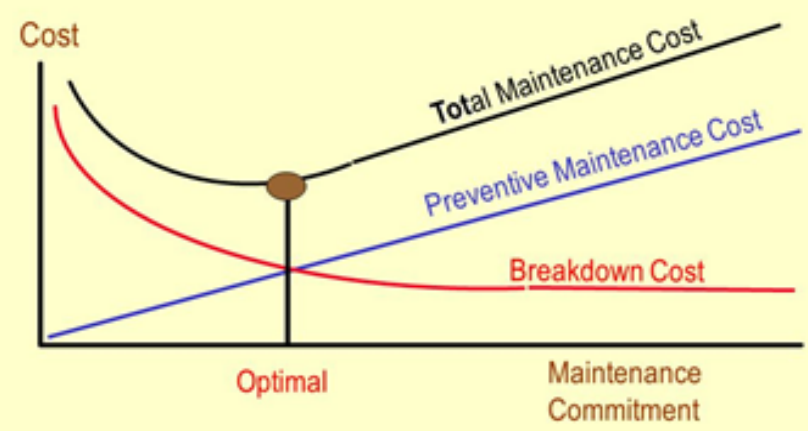

Figure 1. Maintenance costs

Operational variable

The variables used in this research are:

1. Action $=$ The amount of damage is expected for $n$ months

2. $\mathrm{N}=$ The number of the machine

3. Pn $=$ The probability of machine damage in $\mathrm{n}$ months

4. $\mathrm{N}=$ The period of damage/month

5. $\mathrm{TCr}=$ The monthly corrective maintenance costs

6. $\mathrm{C} 2=$ The average cost each damage

7. $\mathrm{Pi}=$ The probability of damaging

8. $\mathrm{i}=$ The month of $\mathrm{n}$

Optimizing analysis (Handoko, 2000):
The amount of damage expected

During n months

$=N \sum_{i}^{n} P n+B(n-1) P 1+B(n-2) P 2+\ldots+B(n-i) P i$

Monthly corrective maintenance costs

$=\frac{\mathrm{NC} 2}{\sum_{i=1}^{i} i \mathcal{P} i}$

The population in this study is the data of customer service maintenance process at PT. ICON+. This study used a non-probability sampling techniques (Cooper, 2006), i.e. arbitrary and subjective sampling. Every member of the population does not have the opportunity to be included in the sample. The type of sampling used in this study was a systematic sampling. In this study used the maintenance data from 2011 to 2014.

\section{RESULTS}

Analysis discussed on the optimization of the maintenance time period that is the most optimal reviewed from minimum maintenance costs. The steps in the optimization analysis are as followed:

1) Determine the estimation of total damages, Knowing the probability of damage occurrence in the machine operated $(\mathrm{Pn})$ must be made in determining an estimated amount of engine damage. The probability of occurrence of machine damage can be found by dividing the number of engine failure occurring in a given month with the amount of damage that occurred in the year.

From the calculation of probability of machine damage (Pn) during 2011-2014, can be known by the number of engine damage cumulative probability of engine failure that occurred for each period. Here can be seen the number of cumulative probability of engine damage for the period 2011-2014 in Table 1:

Table 1. Probability Service Interruption Year 2011-2014

\begin{tabular}{ccccc}
\hline Month & $\mathbf{2 0 1 1}$ & $\mathbf{2 0 1 2}$ & $\mathbf{2 0 1 3}$ & $\mathbf{2 0 1 4}$ \\
\hline 1 & 0,093 & 0,074 & 0,078 & 0,64 \\
2 & 0,111 & 0,119 & 0,094 & 0,60 \\
3 & 0,094 & 0,131 & 0,072 & 0,084 \\
4 & 0,096 & 0,064 & 0,083 & 0,088 \\
5 & 0,048 & 0,097 & 0,075 & 0,061 \\
6 & 0,070 & 0,083 & 0,075 & 0,072 \\
7 & 0,067 & 0,101 & 0,087 & 0,069 \\
8 & 0,099 & 0,044 & 0,052 & 0,083 \\
9 & 0,086 & 0,031 & 0,087 & 0,089 \\
10 & 0,072 & 0,081 & 0,116 & 0,089 \\
11 & 0,089 & 0,072 & 0,074 & 0,131 \\
12 & 0,074 & 0,096 & 0,107 & 0,112 \\
\hline
\end{tabular}

Source: ICON+ (2015) 
After knowing the probability of service interruptions occurence, it can be calculated that the expectiation of service disruption with the formula each month (Handoko, 2000: 162):

$$
\text { Action }=N \sum_{i}^{n} P n+B(n-1) P 1+B(n-2) P 2+\ldots+B(n-i) P i
$$

The results of the calculation of the formula can be seen in the table 2, as followed:

Table 2. The Amount of Estimated Service Damage (Bn)

\begin{tabular}{ccccc}
\hline Month & $\mathbf{2 0 1 1}$ & $\mathbf{2 0 1 2}$ & $\mathbf{2 0 1 3}$ & $\mathbf{2 0 1 4}$ \\
\hline 1 & 0,834 & 0,662 & 0,701 & 0,575 \\
2 & 1,914 & 1,786 & 1,600 & 1,152 \\
3 & 2,956 & 3,122 & 2,390 & 1,976 \\
4 & 4,116 & 4,020 & 3,324 & 2,901 \\
5 & 4,954 & 5,312 & 4,271 & 3,653 \\
6 & 6,036 & 6,570 & 5,294 & 4,557 \\
7 & 7,152 & 8,094 & Some 6,500 & 5,507 \\
8 & 8,644 & 9,270 & 7,488 & 6,645 \\
9 & 10,145 & 10,408 & 8,859 & 7,918 \\
10 & 11,679 & 12,112 & 10,594 & 9,294 \\
11 & 13,484 & 13,742 & 12,124 & 11,156 \\
12 & 15,313 & 15,761 & 14,073 & 13,022 \\
\hline
\end{tabular}

Source: ICON+ (2015)

2) Calculate the Monthly Corrective Maintenance Costs, the first method is to determine and find the average cost of corrective maintenance of each damages. The average fee per damage for four consecutive years is $\mathrm{Rp} 1,916,535.69, \mathrm{Rp} 2,208,531.60, \mathrm{Rp} 1,725,118.02$ and Rp 805,116.87.

After finding out the average damage cost, it can be calculated that the corrective maintenance costs amount each month are as followed:

$$
\mathrm{TCr}=\frac{\mathrm{NC} 2}{\sum_{i=1}^{i} \hat{i} \mathcal{P} i}
$$

The results of the calculation of the monthly corrective maintenance cost are as followed:

Table 3. Monthly Corrective Maintenance costs

\begin{tabular}{lc}
\hline Year & Monthly Corrective Maintenance Cost \\
\hline $\mathbf{2 0 1 1}$ & $4.280 .711,50$ \\
$\mathbf{2 0 1 2}$ & $5.064 .609,74$ \\
$\mathbf{2 0 1 3}$ & $3.600 .962,02$ \\
$\mathbf{2 0 1 4}$ & $1.579 .545,43$ \\
\hline
\end{tabular}

Source: ICON+ (2015)

The data in Table 3 can further be used to calculate the costs of minimum maintenance.

3) Determine optimal period, Optimal time period is the period of time that provides the minimum cost results. Steps should be taken to determine the optimal period are:

A) Dividing the estimated amount of machine damage
$(\mathrm{Bn})$ at month maintenance period.

B) Taking a resultof $\mathrm{Bn}$ per month multiplied by the average cost of corrective every month, in order to obtain corrective costs per month.

C) Dividing the cost of preventive maintenance of each machine with maintenance-month period gor preventive maintenance fees each month.

D) Summarizing the corrective costs and preventive maintenance cost per month in order to obtain the total maintenance costs.

Most optimal alternative period for each machine in 2011 is 12 months, in 2012 the optimal period is 12 months, in 2013 the optimal period is 12 months, and in 2014 with a 12 month period. Therefore, the most optimal alternative maintenance period from 2011 to 2014 is every 12 months.

The overall average period obtained from the average preventive maintenance period of 2011 to 2014 which has a minimum cost is explained as followed.

\begin{tabular}{ccc}
\multicolumn{3}{c}{ Table 4. Preventive Maintenance Period with Minimum Cost } \\
\hline Year & Preventive Period & Total Cost each month \\
\hline 2011 & 12 Month & $43.829 .674,06$ \\
2012 & 12 Month & $47.629 .080,64$ \\
2013 & 12 Month & $49.837 .384,78$ \\
2014 & 12 Month & $52.465 .456,85$ \\
total & 48 Month & $193.761 .596,30$ \\
Average & 12 Month & $48.440 .399,08$ \\
\hline
\end{tabular}

Source: ICON+ (2015)

Table 4 shows that the average period of preventive maintenance services that generates minimum charge is 12 months with an average maintenance costs per month to $\mathrm{Rp} 48.0440 .399,08$. The amount is much smaller than the average cost of maintenance that has been done by the company of $\mathrm{Rp} 60,718,907.20$. Thus, the period of preventive maintenance services PT. ICON+ West Java Regional has not been optimal.

4) Determine the efficiency maintenance engineering, the effeciency of engine maintenance can be discovered by comparing the level of corrective maintenance cost with preventive cost. Once the results are known, it can show the type of maintenance which hasthe smallest level of costs.

Table 5. Comparison of Average Maintenance Costs Each Month Period of 2011-2014

\begin{tabular}{cccc}
\hline Year & $\begin{array}{c}\text { Preventive } \\
\text { Cost }\end{array}$ & $\begin{array}{c}\text { Corrective } \\
\text { Cost }\end{array}$ & $\begin{array}{c}\text { The } \\
\text { Difference }\end{array}$ \\
\hline 2011 & $43.829 .674,06$ & $4.280 .711,50$ & $39.548 .962,56$ \\
2012 & $47.629 .080,64$ & $5.064 .609,74$ & $42.564 .470,90$ \\
2013 & $49.837 .384,78$ & $3.600 .962,02$ & $46.236 .422,76$ \\
2014 & $52.465 .456,85$ & $1.579 .545,43$ & $50.885 .911,41$ \\
Total & $193.761 .596,33$ & $14.525 .828,70$ & $179.235 .767,63$ \\
Average & $48.440 .399,08$ & $3.631 .457,17$ & $44.808 .941,91$ \\
\hline
\end{tabular}

Source: ICON+ (2015) 
Table 5 shows a comparison of the average per month between the cost of preventive maintenance and corrective maintenance costduring the period of 2011 to 2014. When the PT. ICON + West Java Regional implement a preventive maintenance system, the cost is Rp 48,440,399.08. Meanwhile, the system of corrective maintenance costs is $\mathrm{Rp} 3,631,457.17$ and the total cost of maintenance is $\mathrm{Rp} 52,071,856.26$. The number is smaller compared to the costs incurred by the company so far by Rp 105,169,634.85 for corrective maintenance and, $\operatorname{Rp} 60,718,907.17$ for preventive maintenance with a total maintenance cost of $\operatorname{Rp} 165,888,542.02$. This shows that the maintenance the company applied has not been efficient.

\section{DISCUSSION}

The results obtained from the analysis of the research result on the maintenance of customer service process PT. Indonesia Comnets Plus West Java Regional, we obtained the discussion as followed:

1. Implementation of the maintenance of the customer service process in PT. ICON + West Java is using the preventive maintenance and corrective maintenance systems. Preventive maintenance of the company includes tidying up cable in crossroad points and providing housekeeping at the Point of Presence (POP) backbone. Meanwhile, corrective maintenance of the company includes improvements through the NOC system in PT. ICON + Center and repair directly in the field or the user's location.

2. Costs arising from maintenance services include: A. Preventive Maintenance Costs The cost of preventive maintenance includes:

a. Cost of Human Resources: (i) Coordinator, (ii) FOT Technicians, (iii) FOC Technicians, (iv) Administrator Office, (v) Driver.

b. Fiber Optic Cable (FOC) Tools: (i) Car Rent (gas included), (ii) Optical Power Meter (OPM) Rent, (iii) Fiber Identifier Rent, (iv) Laptop Rent, (v) Portable Global Positioning System,( vi) 5.5 KVA Generator Rent, (vii) Other Work Tools.

c. Fiber Optic Transmission (FOT) Tools: (i) Bert Test Rent, (ii) Nokia Terminal Service Rent.

d. Office Management: (i) Office Stationary and Barrack

The amount of preventive maintenance costs incurred during the period of four years beginning in 2011-2014 is Rp 2,914,507,545.00 with an average per month of Rp 60,718,907.00.

B. Corrective Maintenance Costs

a. Cost of Human Resources: (i) Coordinator, (ii) Jointer, (iii) Jointer Assistant, ( iv) FOT Technicians, (v) FOC Technicians, (vi) Patrol Technician, (vii) Administrator Office, (viii) Driver. b. Fiber Optic Cable (FOC) Tools: (i) Car Rent (including fuel), (ii) Patrol Vehicle Rent (including fuel), (iii) Optical Time Domain Reflectometer (OTDR) Rent, (iv) Splicer Rent, (v) Optical Power Meter (OPM) Rent, (vi) Fiber Identifier Rent, (vii) Laptop Rent, (viii) Global Positioning System (GPS) Portable, (ix) Handy Talkie, (x) 5.5 KVA Generator Rental, (xi) Other Work Tools.

c. Fiber Optic Transmission (FOT) Tools: (i) Rent Bert Test, (ii) Nokia Terminal Service Rent.

d. Office Management: (i) Office Stationary and Barrack

The amount of corrective maintenance costs incurred during the period of four years throughout 2011-2014 is Rp 5,048,142,473.00 with an average per month of Rp 105,169,635.00.

3. The corrective maintenance system of the company can be optimal when the probability of damage to the service on average each year is 14.542 . The average cost of corrective maintenance is $\mathrm{Rp} 3,631,457.17$, which is lower than the cost incurred by the company which is $\mathrm{Rp}$ 105,169,635.00. Meanwhile, preventive maintenance system can be optimized if it is implemented with an average time of each service by 12 months with an average maintenance costs per period amounted to Rp 48,440,399.08.

\section{CONCLUSION}

The conclusions that can be drawn from the research result and analysis conducted in PT. Indonesia Comnets Plus (ICON +) West Java Regional are as followed:

1. PT. Indonesia Comnets Plus West Java Regional introduced a system of preventive and corrective maintenance services. Because they operate in the field of telecommunication networks and services, there are nine services with three types of damage in the maintenance system. Costs incurred in preventive and corrective maintenance are cost of human resources, fiber optic cable, fiber optic transmission devices, and office management. Maintenance costs incurred by the company on average each month is $\mathrm{Rp} 60,718,907.00$ for preventive maintenance and $\mathrm{Rp} 105,169,635.00$ for corrective maintenance.

2. The period of maintenance for the nine such services is divided into three levels. The first level is super backbone which should be maintained every two months. The second level is the backbone level which should be maintained every six months. And the third level is the distribution maintenance every year. The amount of the average cost of maintenance per month is $\mathrm{Rp} 60,718,907.00$ for preventive maintenance and corrective maintenance of $\operatorname{Rp~105,169,635.00~with~the~}$ total maintenance cost of Rp 165,888,542.00 which indicates that the policy of maintenance period of the company is still not optimal because it is higher than 
the results of analysis which isRp 48,440,399.08 for preventive maintenance and corrective maintenance for Rp 3,631,457.17 with the total cost of maintenance of Rp 52,071,856.26.

Based on the conclusions, we suggest the company to: 1) Consider the implementation of a policy of maintenance services running in more detail such as scheduled maintenance, the costs incurred, the extent of damage, repair, and maintenance cost aspects. Reconsider the policy application of maintenance services in order to obtain a more efficient maintenance system derived from the analysis of maintenance cost data on average each month of $\mathrm{Rp} 48,440,399.08$ for preventive maintenance, $\operatorname{Rp} 3,631,457.17$ for corrective maintenance, and the total cost of maintenance of USD 52,071,856.26. 2) Reconsider the policy application of maintenance services by implementing preventive maintenance period every 12 months or a year to save on maintenance costs incurred by the company. Implement a preventive maintenance policy in an optimal and cost efficient maintenance and improvements to the operation of the machine by technicians who really understand the conditions of service in accordance to the direction of the optimal maintenance policy.

\section{BIBLIOGRAPHY}

Agustin, Luci Dwi dan A. Holil Noor Ali. 2012. Tata Kelola Infrastruktur TI dan Non TI di Jurusan
Sistem Informasi ITS.Jurnal Teknik, Vol 1, No 1, 1-6. Cooper, Donald R. dan Pamela S. Schindler. 2006. Metode Riset Bisnis Volume 1 (Edisi Kesembilan). New York: McGraw-Hill.

Corder, Antony. 1996. Teknik Manajemen Pemeliharaan. Jakarta: Erlangga.

Handoko, T Hani. 2000. Dasar-dasar Manajemen Produksi dan Operasi. Yogyakarta: BPFE.

Heizer, Jay dan Barry Render. 2011. Manajemen Operasi Buku Kedua (Edisi Sembilan). Jakarta: Salemba Empat.

Kabib, Masruki. 2009. Optimasi Perawatan di Industri Manufaktur.Teknik Mesin.

Kosasih, Sobarsa. 2009. Manajemen Operasi. Jakarta: Mitra Wacana Media.

Ma’arif, Mohamad Syamsul \& Hendri Tandjung. 2003. Manajemen Operasi. Jakarta: PT. Grasindo.

Manajemen PT. ICON+. 2014. Laporan Tahunan Perusahaan Tahun 2013. Jakarta: PT. ICON+.

Margono. 2006. Manajemen Pemeliharaan dan Perawatan Mesin.Jurnal Teknik Mesin, Volume 4, 42-48.

Subakir. 2010. Pengaruh Biaya Pemeliharaan Mesin Terhadap Peningkatan Pendapatan Jasa PT. Triperkasa Aminindah Surabaya. Akuntansi.

Suroso, Arif Imam. 2014. Pengembangan Sistem Informasi dengan Menggunakan Pendekatan In dan Outsourcing di Peru-sahaan. Sistem Informasi Manajemen. 